\title{
Eco-friendly management of major diseases in jute (Corchorus olitorius L.)
}

\author{
P. N. Meena ${ }^{1 *}$, A. Roy $^{3}$, B. S. Gotyal ${ }^{1}$, S. Mitra ${ }^{2}$ and S. Satpathy ${ }^{1}$ \\ ${ }^{1}$ Crop Protection Division, Central Research Institute for Jute and Allied Fibres (CRIJAF), Barrackpore, Kolkata-700120 \\ (West Bengal), INDIA \\ ${ }^{2}$ Crop Production Division, Central Research Institute for Jute and Allied Fibres (CRIJAF), Barrackpore, Kolkata-700120 \\ (West Bengal), INDIA \\ ${ }^{3}$ AINP on jute and allied fibre, Uttara Banga Krishi Vishwavidyalaya (UBKV), Pundibari, Coochbehar-736165 \\ (West Bengal), INDIA \\ *Corresponding author. E-mail: pnshera@ yahoo.co.in
}

Received: July 08, 2014 Revised received: September 06, 2014 Accepted: October 25, 2014

\begin{abstract}
Field experiment was conducted for disease management with seven eco-friendly treatments in Corchorus olitorius jute during 2012-2013 under randomized block design (RBD) in three replications with variety JRO-524. The ecofriendly treatment $50 \% \mathrm{~N}: \mathrm{P}: \mathrm{K}+$ seed treatments with Azotobacter and phosphorus solubilizing bacteria (PSB) @ 5g/Kg+ Trichoderma viride (seed treatment @ 5g/Kg of seed and soil application @ 2Kg/ha at 21DAS) + Psuedomonas fluorescens spray @ 0.2\% at 45DAS was found superior with minimum per cent disease incidence (3.46 and 1.43\%) as compared to control (13.17 and 4.96\%). The second best treatment was found with Farm yard manure (FYM) @ 5t/ha + seed treatment with Azotobecter and PSB @ 5g/Kg+ T. viride (seed treatment $@ 5 \mathrm{~g} / \mathrm{Kg}$ of seed and soil application @ 2Kg/ha 21DAS)+P. fluorescencs spray @ $0.2 \%$ at 45DAS and showed 3.61 and 2.0\% disease incidence. The treatment with N: P: K@ 60:30:30 and seed treatment with carbendazim 50WP @ $2 \mathrm{~g} / \mathrm{Kg}$ at $45 \mathrm{DAS}$ showed 4.56 and $2.10 \%$ disease incidence. Dry fibre yield was highest $(30.33 \mathrm{q} / \mathrm{ha})$ in the plots treated with FYM @ 5t/ha + seed treatment with Azotobacter and PSB @ 5g/Kg+ T. viride (seed treatment @ 5g/Kg of seed and soil application @ 2Kg/ha at 21DAS) + P. fluorescencs spray @ 0.2\% at 45DAS) and it was lowest in untreated control (15.69 q/ha).Variation in yield was attributed due to difference in plant height.
\end{abstract}

Keywords: Bioagents, Biofertilizers, Ecofriendly management, Jute and Macrophomina phaseolina

\section{INTRODUCTION}

Jute is an important bast fibre crop next to cotton. It is mainly grown in Bangladesh, China, India, Nepal, Thailand, Myanmar, Pakistan and Bhutan. The area under jute cultivation during 2013-14 was 8.27 lakh hectares with production of 114 lakh bales. In India jute cultivation is confined to the states of West Bengal, Bihar, Assam, Andhra Pradesh, Orissa, Meghalaya and some parts of Nagaland with an area of $0.62,0.14,0.07,0.02,0.02$ and 0.02 million hectares and production of $9.40,1.28,0.74,0.19,0.11$ and 0.05 million bales dry fiber respectively. The total productivity of jute in India is $23.53 \mathrm{q} / \mathrm{ha}$ with an export earnings from jute based products is to the tune of 2050 crore per annum (Anonymous, 1990, 2013). Jute fibre is used for making bags, decorative, textiles and geo textiles, and its sticks are also used for fuel, door panels of automobiles and for making false ceiling boards. Stem rot and Root rot of jute caused by $M$. phaseolina (Tassi) Goid is economically the most important dreadful diseases of jute affecting both the cultivated species $C$. olitorius L. and $C$. capsularis $\mathrm{L}$. resulting in yield loss and fiber quality. The other diseases compelling jute crop to suffer are seedling blight, leaf blight, anthracnose and leaf mosaic (Roy et al., 2008). Among them disease caused by M. phaseolina is devastating. M. phaseolina (Tassi) Goid is the pycnidial stage of the pathogen. The pycnidial coupled with sclerotial stage are primarily responsible for the infection of disease in jute (Ghosh, 1983; Mandal, 1990). The disease is seed, soil and air borne in nature which continuously damage the crop starting from germination to maturity in both seed and fiber crops (De, 2013). Seed is an important source of primary inoculum then infection through soil. The incidence of stem rot epidemic can be gauged from primary infection, as secondary infection is usually four times the primary infection (Anonymous, 2006). All the plant parts are vulnerable to the diseases initiating from seed germination till harvest and causes severe infection up to tune of $35-40 \%$. March sown crop is more prone to stem rot and root rot. Cloudy condition, heavy rainfall and humid weather and temperature of $\left(34 \pm 1^{\circ} \mathrm{C}\right.$ ) prevail the disease to become more severe (Rao, 1980; Ghosh, 1983; Mandal, 1990). Due to wide host range and changing climatic conditions management of this pathogen has become cumbersome. Similarly, 
there are no resistant /tolerant varieties in C. olitorius and $C$. capsularis (Kar et al., 2009). Over relying on chemicals also develop fungicide-resistant strains of plant pathogens, resurgence, lethality to beneficial organism and loss of biodiversity. Thus, due to the importance of disease and difficulty of its control through prevalent methods, it seems that there is urgent need for the development of integrated control by a combination of several methods that are effective coupled with eco-friendly in nature. These ecofriendly management modules are cost effective, durable, free from environment pollution and relatively safe for farmers who can't rely on synthetic pesticides. Therefore, an attempt has been made to manage the diseases caused by $M$. phaseolina using (bioagents, fungicides, biofertilizer, etc.) in ecofriendly management strategies.

\section{MATERIALS AND METHODS}

Field experiment was conducted for ecofriendly disease management of $M$. phaseolina infecting Corchorus olitorius (jute) during 2012-2013 at experimental plots of Uttar Banga Krishi Viswavidyalaya (UBKV) Coochbehar in randomized block design (RBD) with three replications using variety, JRO-524 in a plot size of $3 \times 5 \mathrm{~m}^{2}$ with row to row spacing 30 $\mathrm{cm}$ and plant to plant $10 \mathrm{~cm}$ after thinning at 20-25 days after sowing. The recommended integrated package of practices were followed as and where required. Different integrated treatments includes: $\mid \mathrm{T}_{1}-$ $\mathrm{N}: \mathrm{P}: \mathrm{K} @$ 60:30:30 + seed treatment with carbendazim @ $2 \mathrm{~g} / \mathrm{Kg}$ at $45 \mathrm{DAS}, \mathrm{T}_{2}-50 \% \mathrm{~N}: \mathrm{P}: \mathrm{K}+$ seed treatment with Azotobacter and phosphorus solubilizing bacteria (PSB) @ 5g/Kg at 45DAS, T $3-50 \% \mathrm{~N}: \mathrm{P}: \mathrm{K}+$ seed treatment with Azotobacter and PSB @ $5 \mathrm{~g} / \mathrm{Kg}+T$. viride (seed treatment _@ $5 \mathrm{~g} / \mathrm{Kg}$ of seed and soil application @ 2Kg/ha at 21DAS) + P. fluorescens spray @ 0.2\% at 45DAS, T $4-50 \%$ N:P:K + seed treatment with Azotobacter and PSB @ 5g/Kg + spraying of IAA @ $0.01 \%$ at $45 \mathrm{DAS}, \mathrm{T}_{5}$-FYM @ 5t/ha + seed treatment with Azotobacter and PSB @ 5g/Kg $+T$. viride (seed treatment @ $5 \mathrm{~g} / \mathrm{Kg}$ of seed and soil application@2Kg/ha at 21DAS) + P. fluorescencs spray@0.2\% at 45DAS, T6- FYM @ 5t/ha + seed treatment with Azotobacter and PSB @ 5g/Kg + IAA @ $0.01 \%$ at $45 \mathrm{DAS}, \mathrm{T}_{7^{-}}$Untreated control. The $T$. viride was applied through mixed with seed and soil. While, the $P$. fluorescens and IAA applied through spraying. However, the basal dose of fertilizers was broadcasted in the field and farm yard manure directly mixed in the soil. The data were recorded at fortnightly intervals from 15 days after sowing till harvesting. The incidence of diseases was recorded as percentage. Plant height $(\mathrm{cm})$, basal diameter $(\mathrm{cm})$, green weight $(\mathrm{q} / \mathrm{ha})$ and fiber yield ( $\mathrm{q} / \mathrm{ha}$ ) were also recorded and the data were subjected to statistical analysis for the test of significance.

\section{RESULTS AND DISCUSSION}

Data obtained (Table 1) for two years were pooled and analyzed to conclude the results of applied integrated management of major disease. Eco friendly treatments indicated that treatment with $50 \% \mathrm{~N}: \mathrm{P}: \mathrm{K}+$ seed treatment with Azotobacter and PSB @ $5 \mathrm{~g} / \mathrm{Kg}+T$. viride (seed treatment @ $5 \mathrm{~g} / \mathrm{Kg}$ of seed and soil application @ 2Kg/ha at 21DAS) + P. fluorescens spray@ $0.2 \%$ at $45 \mathrm{DAS}$ was found superior among the treatments in controlling of diseases. The per cent incidence of disease stem rot and root rot was 3.46 and $1.43 \%$ respectively, while, in check it was 13.17 and $4.96 \%$, respectively. The second best treatment was FYM @ 5t/ha + seed treatment with Azotobacter and PSB @ 5g/Kg +7 . viride (seed treatment @ 5g/Kg of seed and soil application @ 2Kg/ha at 21DAS) + P. fluorescencs spray @ 0.2\% at 45DAS showed 3.61 and $2.0 \%$ incidence of stem rot and root rot diseases. The treatment with N: P: K @ 60:30:30 and seed treatment with carbendazim 50WP @ 2g/Kg at 45DAS resulted 4.56 and $2.10 \%$ incidence. Application of potash @ 50 $-100 \mathrm{~kg} \mathrm{~K} \mathrm{~K}_{2} \mathrm{O} / \mathrm{ha}$ as a basal dose can check the disease to a considerable extent (Cheng and Tu, 1970). Stem rot disease incidence decreased with application of micronutrient (Zn, Fe, Bo) along with N: P: K (Thakur ji, 1974; Thakur ji et al., 1976). The results revealed that the variation in basal diameter was non-significant but significant variation among the treatments was found in plant height being highest in $\mathrm{T}_{1}$ treatment $(329 \mathrm{~cm})$ consisting with $\mathrm{N}$ : P: K fertilizer and carbendazim fungicide. Dry fibre yield was highest $(30.33 \mathrm{q} / \mathrm{ha})$ in the plots treated with $\mathrm{T}_{5}$ treatment including FYM @ 5t/ha + seed treatment with Azotobacter and PSB @ $5 \mathrm{~g} / \mathrm{Kg}+$ T. viride (seed treatment @ $5 \mathrm{~g} / \mathrm{Kg}$ of seed and soil application@2Kg/ha at 21DAS) + P. fluorescencs spray @ $0.2 \%$ at 45DAS) and while it was lowest in untreated control (15.69 q/ha) and in carbendazim treatment, it was $28.42 \mathrm{q} / \mathrm{ha}$. Yield variation was due to variation in respect of plant height. Strain of T. viride, Aspergillus niger (Strain AN-27) and some other species of fluorescent Pseudomonas have been established as very effective biocontrol agents for stem and root rot in jute (Roy et al., 2008; Srivastava and Singh, 2009). Antagonastic fungal isolates of Trichoderma, Gliocladium, Aspergilius, Penicillium and PGPR isolates showed promising antagonistic properties inhibiting highly virulent isolates ( $\mathrm{R}$ 9) of $M$. phaseolina to a great extent (Bandopadhyay et al.,2006). Eco-friendly treatments with $T$. harzianum as seed treatment alone or in combination with $P$. fluorescens and foliar spray with chemical fungicides significantly reduced the Alternaria blight disease of mustard (Meena et al., 2011). The treatment with soil application of $T$. viride thrice was found best in controlling seedling blight, collor rot, stem rot and root rot diseases of jute and giving minimum per cent disease incidence as compared to control (Srivastava et al., 2010). Despite 
Table 1. Per cent incidence of stem rot and root rot diseases in jute and treatments impact on plant height, basal diameter, green weight and fiber yield per hectare during 2012-13.Values in parentheses are per cent disease reduction over control.

\begin{tabular}{|c|c|c|c|c|c|c|}
\hline Treatments & $\begin{array}{c}\text { Stem rot } \\
\text { (PDI) }\end{array}$ & $\begin{array}{c}\text { Root rot } \\
\text { (PDI) }\end{array}$ & $\begin{array}{l}\text { Plant } \\
\text { height } \\
\text { (cm) }\end{array}$ & $\begin{array}{c}\text { Basal } \\
\text { diameter } \\
(\mathbf{c m})\end{array}$ & $\begin{array}{l}\text { Green } \\
\text { weight } \\
\text { (q/ha) }\end{array}$ & $\begin{array}{l}\text { Fiber } \\
\text { yield } \\
\text { (q/ha) }\end{array}$ \\
\hline $\begin{array}{l}\mathrm{T}_{1}-\mathrm{N}: \mathrm{P}: \mathrm{K} @ 60: 30: 30+\text { seed treatment } \\
\text { with carbendazim @ } 2 \mathrm{~g} / \mathrm{Kg} \text { at } \\
\text { 45DAS }\end{array}$ & $\begin{array}{c}4.56 \\
(65.3)\end{array}$ & $\begin{array}{c}2.10 \\
(57.6)\end{array}$ & 329 & 1.4 & 505 & 28.42 \\
\hline $\begin{array}{l}\mathrm{T}_{2^{-}} 50 \% \mathrm{~N}: \mathrm{P}: \mathrm{K}+\text { seed treatment with } \\
\text { Azotobacter and PSB @ 5g/Kg at } 45 \\
\text { DAS }\end{array}$ & $\begin{array}{c}6.97 \\
(47.0)\end{array}$ & $\begin{array}{c}2.52 \\
(49.1)\end{array}$ & 298 & 1.3 & 438 & 26.69 \\
\hline $\begin{array}{l}\mathrm{T}_{3}-50 \% \mathrm{~N}: \mathrm{P}: \mathrm{K}+\text { seed treatment with } \\
\text { Azotobecter and PSB @ } 5 \mathrm{~g} / \mathrm{Kg}+T \text {. } \\
\text { viride (seed treatment @ } 5 \mathrm{~g} / \mathrm{Kg} \text { of } \\
\text { seed and soil application @ } 2 \mathrm{Kg} / \mathrm{ha} \\
\text { at } 21 \mathrm{DAS})+P . \text { fluorescens spray @ } \\
0.2 \% \text { at } 45 \mathrm{DAS}\end{array}$ & $\begin{array}{c}3.46 \\
(73.7)\end{array}$ & $\begin{array}{c}1.43 \\
(71.1)\end{array}$ & 309 & 1.4 & 498 & 29.19 \\
\hline $\begin{array}{l}\mathrm{T}_{4}-50 \% \mathrm{~N}: \mathrm{P}: \mathrm{K}+\text { seed treatment with } \\
\text { Azotobacter and PSB @ 5g/Kg + } \\
\text { spraying of IAA @ } 0.01 \% \text { at } 45 \mathrm{DAS}\end{array}$ & $\begin{array}{c}8.38 \\
(36.3)\end{array}$ & $\begin{array}{c}3.65 \\
(26.4)\end{array}$ & 295 & 1.4 & 456 & 29.38 \\
\hline $\begin{array}{l}\mathrm{T}_{5}-\mathrm{FYM} @ 5 \mathrm{t} / \mathrm{ha}+\text { seed treatment } \\
\text { with Azotobacter and PSB @ 5g/ } \\
\mathrm{Kg}+\text { T.viride (seed treatment @ 5g/ } \\
\mathrm{Kg} \text { of seed and soil application @ } \\
2 \mathrm{Kg} / \mathrm{h} \text { at } 21 \mathrm{DAS})+P . \text { fluorescencs } \\
\text { spray @ } 0.2 \% \text { at } 45 \mathrm{DAS}\end{array}$ & $\begin{array}{c}3.61 \\
(72.5)\end{array}$ & $\begin{array}{c}2.0 \\
(59.6)\end{array}$ & 298 & 1.3 & 453 & 30.33 \\
\hline $\begin{array}{l}\mathrm{T}_{6}-\mathrm{FYM} @ 5 \mathrm{t} / \mathrm{ha}+\text { seed treatment } \\
\text { with Azotobacter and PSB @ } 5 \mathrm{~g} / \mathrm{Kg} \\
+\mathrm{IAA} @ 0.01 \% \text { at } 45 \mathrm{DAS}\end{array}$ & $\begin{array}{c}5.77 \\
(56.1)\end{array}$ & $\begin{array}{c}3.53 \\
(28.8)\end{array}$ & 291 & 1.3 & 457 & 26.08 \\
\hline $\mathrm{T}_{7}$ - Untreated control & $\begin{array}{c}13.17 \\
(0.0)\end{array}$ & $\begin{array}{l}4.96 \\
(0.0)\end{array}$ & 247 & 1.2 & 287 & 15.69 \\
\hline $\mathrm{CD}(\mathrm{P}=0.05)$ & 1.4 & .84 & 1.75 & .078 & 2.2 & 1.92 \\
\hline
\end{tabular}

fungicide remains more effective in reducing diseases in plants, increasing public concern about environmental health is proving to be major hindrance in use of chemical pesticides including fungicides. Hence, use of low dose of fungicides, integrated with other means like bioagents, biofertilizer, hormones, inorganic fertilizers and farm yard manure seems to be best method of ecofriendly disease management without environmental pollution.

\section{Conclusion}

Stem rot and root rot of jute caused by M. phaseolina are major diseases of jute (C. olitorious) in India that results in economic losses. There is no another alternative and effective method to manage this deadly disease in the field. So, it may be concluded that treatment with $50 \% \mathrm{~N}: \mathrm{P}: \mathrm{K}+$ seed treatment with Azotobacter and PSB @ 5g/Kg + T. viride (seed treatment @ 5g/Kg of seed and soil application @ 2Kg/ha at 21DAS) + P. fluorescens spray @ 0.2\% at 45DAS was found to be more superior ecofriendly treatment in controlling of stem rot and root rot disease of jute.

\section{ACKNOWLEDGEMENT}

The authors are grateful to the Director, CRIJAF, Barrackpore, Central Research Institute for Jute and Allied Fibers, Barrackpore, Kolkata, and All India Network Project for providing support to undertake the study.

\section{REFERENCES}

Anonymous, (1990). Fifty years of Research on Jute and Allied Fibres. Agriculture (1948-1997), Central Research Institute for Jute and Allied Fibres. Barrackpore.

Anonymous, (2006). Annual Report. Central Research Institute for Jute and Allied Fibers, Barrackpore.

Anonymous, (2013). Annual Report. Central Research Institute for Jute and Allied Fibers, Barrackpore.

Bandopadhyay, A.K., Bandopadhyay, A., and Majumder, A. (2006). Antagonistic effect of Trichoderma, Gliocladium, Aspergilius, Penicillium and PGPR isolates on highly virulent isolates (R 9) of M. phaseolina. J. Mycopatho. Res., 44: 323-330.

Cheng, Y.H., and Tu, C.C. (1970). Effect of nitrogen and potash fertilizer on the occurrence on stem rot of jute. Res. Rep. Taiwan Fibre Exp. Station, TARI. N.S. No-6. 
De, R.K. (2013). Effect of date of sowing on the incidence of stem rot of jute (Corchorus olitorious L.) caused by Macrophomina phaseolina. J. Mycopathol, Res, 51 (2):251-257.

Ghosh, T. (1983). "Handbook on jute" FAO Plant production and protection paper. 51: 219.

Kar, C.S., Kundu, A., Sarkar, D., Sinha, M.K. and Mahapatra, B.S. (2009). Genetic diversity in jute (Corchorus spp.) and its utilization: a review. Indi. J. Agric. Sci., 79:587-91.

Mandal, R.K. (1990). Jute diseases and their control. In: Proceedings of National Workshop cum Training on Jute, Mesta, Sunhemp and Ramie. Central Research Institute for Jute and Allied Fibers, Barrackpore, West Bengal, India.

Meena, P.D., Awasthi, R.P., Godika, S., Gupta, J.C., Kumar, A., Sandhu, P.S., Sharma, P. and Rai, P.K. (2011). Eco-friendly approaches managing major diseases of Indian mustard. World Applied Sci. Journal, 12 (8): $1192-1195$

Rao, P.V. (1980). Effect of rainfall and temperature on yield of tossa jute. Indi. J. Agric. Sci., 50: 608-611.

Roy, A., De, R.K. and Ghosh, S.K. (2008). Diseases of bast fiber crops and their management in jute and allied fibers, pp.327. In: Karmakar, P.G., Hazara, S.K., Subramanian T.R., Mandal, R.K., Sinha, M.K. and Sen, H.S. (Eds.). Updates Production Technology, Central Research Institute for Jute and Allied Fibers, Barrckpore, West Bengal, India.

Srivastava, R.K. and Singh, R.K. (2009). Evaluation of consortium of bioagents for the management of Macrophomina phaseolina disease complex in the jute (Corchorus olitorius).5th International Conference on Plant Pathology in the Globalized Era, Nov. 10-13, 2009, Organized by Indian Phytopathological Society, Indian Agricultural Research Institute, New Delhi, India. 656 (S-15): 351.

Srivastava, R.K., Singh, R.K., Kumar, N. and Singh, S. (2010). Management of Macrophomina disease complex in jute (Corchorus olitorius) by Trichoderma viride. J. of Bio. Control, 24 (1): 77-79.

Thakur ji, Hira lal and Singh. (1976). Influence of micronutrient on incidence of stem rot of Capsularis jute. Indian J. Mycol. Plant Pathol. 6: 96.

Thakur ji. (1974). Influence of N: P: K on stem rot of Capsularis jute. Indian J. Mycol. Pl. Pathol. 4:117-120. 